\title{
Effect of Processing Parameters on the Swelling Behaviour of Cement-bonded Briquettes
}

\author{
Maneesh SINGH and Bo BJÖRKMAN \\ Division of Process Metallurgy Luleå University of Technology SE-971 87, Luleå, Sweden. E-mail: maneesh@ludd.luth.se, \\ Bo.Bjorkman@km.luth.se
}

(Received on June 10, 2002; accepted in final form on September 22, 2003)

\begin{abstract}
The use of cement-bonded agglomerates of iron-rich by-products generated in iron and steel plants as burden material for blast furnaces is becoming quite common. It has been observed that under certain conditions the briquettes containing pellet-fines show a tendency to swell catastrophically when reduced at $900-1000^{\circ} \mathrm{C}$ using carbon monoxide as a reducing agent. This swelling is dependent upon a number of processing parameters, such as: composition of briquettes, particle size of raw material, amount of cement, composition of cement, and coke content. It is not dependent upon the size of agglomerate or hydration period. From the optical micrographs, it is apparent that the swelling may be attributed to the formation of small spheroidal iron particles that move apart, thereby causing swelling. This paper describes the effect of various processing parameters that cause the abnormal swelling in cement-bonded briquettes made of pellet-fines.
\end{abstract}

KEY WORDS: cement-bonded agglomerates; briquettes; blast furnace; swelling; reduction; pellets, processing.

\section{Introduction}

During the course of steel production a wide variety of iron-rich by-products are generated. Most of the time, these by-products are sintered and recycled back to the blast furnace. In recent years, the cold-bond agglomeration process has emerged as an alternative to the sintering process. In this process, various iron-rich steel-plant by-products are mixed together with a binder and agglomerated. Such cement-bonded briquettes have been in regular use as a burden material in a number of plants. ${ }^{1,2)}$ A common observation among the plant operators has been that addition of cold-bonded briquettes comprising up to $5 \%$ of the burden material does not pose any major problem; but at higher percentages, the blast furnace starts operating in an erratic manner. ${ }^{3}$ This is often attributed to the disintegration of briquettes inside the blast furnace. The destruction of cementitious phase is the major cause for the disintegration of cement-bonded agglomerates; but it is suspected that the abnormal swelling of the agglomerates may be aggravating the problem. Hence, an understanding of the conditions under which the cold-bonded briquettes swell is essential.

The swelling of burden material is a characteristic only of indurated pellets. It does not take place in the case of lump ore or sinters. The swelling is a complex phenomenon in which a number of parameters play an important role. This has made it difficult to develop a generalised swelling model. It is now generally accepted that the swelling in pellets is due to selective nucleation and growth of iron whiskers. When these iron whiskers grow, they push the adjoining grains, resulting in swelling. ${ }^{4)}$

It has been found that the swelling of indurated pellets depends upon a number of processing parameters. Some of these factors are: induration time and temperature, size distribution of ground ore, presence of alkalies, amount and composition of slag, porosity of pellets and strength of pellets.
Some important factors that affect the swelling of indurated pellets are:

Pellet Characteristics: The amount of gangue present in the pellets is an important parameter affecting swelling. It has been shown that in pellets the tendency to swell decreases with an increase in gangue content due to the increased formation of minor slag bonding. It has also been observed that the slag compositions in the system $\mathrm{CaO}-\mathrm{MgO}-\mathrm{Al}_{2} \mathrm{O}_{3}-\mathrm{SiO}_{2}$ that give vitreous slag bonding result in catastrophic swelling. The formation of vitreous slag causes loss of slag bonding that could resist the stress caused by the volume expansion. This normally happens when the basicity $\left[(\mathrm{CaO}+\mathrm{MgO}) /\left(\mathrm{SiO}_{2}+\mathrm{Al}_{2} \mathrm{O}_{3}\right)\right]$ is between 0.5 and 1. Similarly, if the alkalis are present in the pellets, they can react with the pellet slag and lower its melting point, thereby causing abnormal swelling. ${ }^{5-8)}$

Free Lime: The presence of free lime leads to catastrophic swelling in pellets due to the dissolution of $\mathrm{CaO}$ on the surface of $\mathrm{FeO}$, leaving only a few nucleation sites. From these few nucleation sites the whiskers can grow, leading to the excessive swelling. ${ }^{9}$

Size of Pellets: The swelling decreases with the increase in the size of the pellets. This is probably due to the decline in the rate of reduction as the pellet size increases. ${ }^{10)}$

Swelling has also been observed in the cement-bonded agglomerates, although not much work has been done on the swelling of cold-bonded agglomerates. In the case of cold-bonded agglomerates, the swelling has been observed in conjunction both with and without the formation of iron whiskers. The conditions for swelling of indurated pellets differ from the conditions for the swelling of cement-bonded agglomerates, but not much work has been done in that direction.

In this paper the effect of various processing parameters on the swelling of cement-bonded briquettes have been discussed. 


\section{Materials and Methods}

\subsection{Raw Materials}

Nine raw materials from an integrated steel plant were used for the study. One of the materials, pellet-fines, was a mixture of fines of Pellet A and Pellet B, two commercially available pellets. During the transportation and handling the weaker pellets break, these broken pellet segments are removed as pellet-fines by sieving before the pellets are charged into blast furnace. The remaining materials were different iron rich slags, sludges and dusts. Even though Manganese slag is not a by-product it has also been included in the composition. This is because it is added during the production of briquettes, since manganese in hot metal is required during the steelmaking process. Ordinary Portland cement was used as a binder. Using these raw materials, two types of briquettes were made. Table 1 gives the chemical analysis of various raw materials, and Table 2 gives the composition of the briquettes.

The particle size analysis, showed a wide range of distribution for all the by-products. While most of the materials ranged from very fine $(-200$ mesh, $75 \mu \mathrm{m})$ to quite coarse $(+9.5 \mathrm{~mm})$, blasting dust and LD dust had only fine fractions.

In one of the experiments eight different types of pellets (Pellets $\mathrm{A}-\mathrm{H}$ ) were also used for the experiments. Pellets A and $\mathrm{B}$ are commercially available and the rest are experimental pellets produced in a small batch. Table 3 gives the chemical composition of the pellets and pellet-fines. It can be seen that the pellet-fines contains relatively higher percentage of $\mathrm{FeO}$ compared to the rest showing that the pellet-fines are not properly oxidised.

\subsection{Preparation of Briquettes}

$900 \mathrm{~g}$ of Mix A or Mix B was ground in a steel ball mill.

Table 1. Chemical analysis of various raw materials.

\begin{tabular}{|c|c|c|c|c|c|c|c|c|c|}
\hline wt $\%$ & $\begin{array}{c}\text { Manganese } \\
\text { slag } \\
\end{array}$ & \begin{tabular}{|c|} 
Slag \\
handling \\
scrap
\end{tabular} & $\begin{array}{l}\text { Pellet- } \\
\text { fines }\end{array}$ & \begin{tabular}{|c|} 
LD \\
converter \\
dust \\
\end{tabular} & $\begin{array}{c}\text { Cutting } \\
\text { slag } \\
\text { (steel- } \\
\text { work) }\end{array}$ & $\begin{array}{c}\text { Cutting } \\
\text { slag } \\
\text { (rolling) }\end{array}$ & Mill scale & \begin{tabular}{|c|} 
Blasting \\
dust
\end{tabular} & Cement \\
\hline $\mathrm{Fe}$ & 2.92 & 58.77 & 66.63 & 64.49 & 86.29 & 76.86 & 72.25 & 85.61 & - \\
\hline $\mathrm{Fe}$ (met) & - & 31.91 & - & 48.50 & 55.53 & 23.20 & 0.47 & 53.00 & - \\
\hline $\mathrm{Fe}^{2+}$ & 0.86 & 14.59 & 2.14 & 8.83 & 22.68 & 34.83 & 57.90 & 25.90 & - \\
\hline $\mathrm{Fe}^{3+}$ & 2.06 & 12.27 & 64.50 & 7.16 & 8.08 & 18.83 & 13.88 & 6.71 & - \\
\hline $\mathrm{Fe}_{x} \mathrm{O}_{y}$ & - & - & - & - & - & - & - & - & 2.67 \\
\hline $\mathrm{MnO}$ & 49.25 & 1.57 & 0.07 & 1.14 & 0.75 & 1.22 & 1.15 & 1.14 & 0.04 \\
\hline $\mathrm{CaO}$ & 11.72 & 14.90 & 0.39 & 15.66 & 0.30 & 0.16 & 0.22 & 0.04 & 64.04 \\
\hline $\mathrm{MgO}$ & 4.07 & 3.35 & 1.45 & 2.42 & 0.05 & 0.10 & 0.04 & 0.04 & 3.34 \\
\hline $\mathrm{Al}_{2} \mathrm{O}_{3}$ & 8.13 & 1.17 & 0.39 & 0.27 & 0.12 & 0.06 & 0.16 & 0.08 & 4.36 \\
\hline $\mathrm{SiO}_{2}$ & 22.43 & 7.98 & 2.21 & 4.65 & 0.72 & 0.75 & 0.86 & 1.35 & 25.45 \\
\hline $\mathrm{P}_{2} \mathrm{O}_{5}$ & 0.05 & 0.21 & 0.03 & 0.11 & 0.04 & 0.02 & 0.02 & 0.04 & 0.03 \\
\hline $\mathrm{K}_{2} \mathrm{O}$ & 1.93 & 0.02 & 0.03 & 0.02 & 0.01 & 0.01 & 0.01 & 0.01 & 1.09 \\
\hline $\mathrm{Na}_{2} \mathrm{O}$ & 0.36 & 0.06 & 0.05 & 0.03 & 0.01 & 0.01 & 0.02 & 0.003 & 0.26 \\
\hline $\mathrm{s}$ & 0.41 & 0.68 & 0.004 & 0.03 & 0.01 & 0.01 & 0.01 & 0.03 & 0.14 \\
\hline C & - & 2.03 & - & 0.82 & 0.10 & 0.12 & 0.06 & 0.58 & 0 \\
\hline Total & 102.83 & 102.47 & 100.09 & 96.68 & 98.49 & 97.58 & 97.63 & 99.36 & 101.66 \\
\hline
\end{tabular}

$150 \mathrm{~g}$ of this mixture and optimum quantity of water (10-15 ml, depending upon the composition and particle size distribution of the raw mixture) were then put in a steel trough and mixed for about a minute, so as to obtain a mouldable paste.

The plastic paste was put in a cylindrical steel mould of $4.2 \mathrm{~cm}$ diameter and compacted first by vibration for fixed period of time $(1.0 \mathrm{~min})$ (using a vibrating machine) and subsequently by compression under fixed load (1.5t) for fixed time (1.0 min) (using a laboratory scale press). The green briquette thus obtained was cured for 28 days in a high humidity chamber. The cured briquettes were dried overnight in an oven maintained at $105^{\circ} \mathrm{C}$.

\subsection{Reduction of Briquettes}

The reduction set-up consisted of two parts: the gas supply and the heating furnace. The gases were supplied from cylinders. The supply of nitrogen and carbon monoxide was controlled using needle valves and flow meters. The gases in the required proportions were mixed in a gas mixer consisting of a tube containing glass beads.

The heating furnace consisted of a Kanthal wire wound tube furnace (length: $100 \mathrm{~m}$, diameter: $12.5 \mathrm{~cm}$ ). A stainless steel tube (length: $135 \mathrm{~cm}$, outer diameter: $6.5 \mathrm{~cm}$ ) closed at the bottom end was placed inside this furnace. A K-type thermocouple placed inside the furnace near the briquette monitored the furnace temperature. The gas mixture, either only nitrogen or a mixture of nitrogen and carbon monoxide $\left(\mathrm{N}_{2}: \mathrm{CO}=60: 40\right)$ at a flow rate of $101 / \mathrm{min}$ entered from the bottom and was burnt at the top by means of an off-gas burner.

For isothermal reduction, the furnace was heated until the desired temperature and then the flow of reducing gas mixture was introduced. A briquette, placed in a high-temperature steel basket, was then lowered into the furnace and suspended from a balance placed above. The briquette was suspended in the region where the deviation was within

Table 2. Composition of briquettes

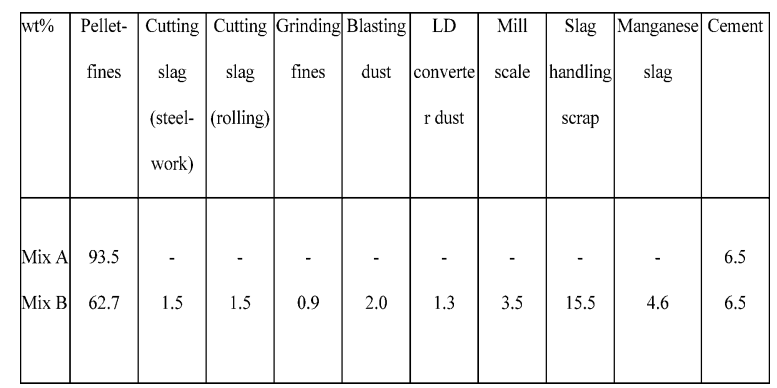

Table 3. Chemical composition of pellets used for the experiments.

\begin{tabular}{|l|c|c|c|c|c|c|c|c|c|}
\hline wt\% & $\mathrm{A}$ & $\mathrm{B}$ & $\mathrm{C}$ & $\mathrm{D}$ & $\mathrm{E}$ & $\mathrm{F}$ & $\mathrm{G}$ & $\mathrm{H}$ & $\begin{array}{c}\text { Pellet- } \\
\text { fines } \\
\text { (PF) }\end{array}$ \\
\hline $\mathrm{Fe}_{2} \mathrm{O}_{3}$ & 94.84 & 94.77 & 95.22 & 95.18 & 96.10 & 95.97 & 95.77 & 95.18 & 92.20 \\
$\mathrm{FeO}$ & 0.44 & 0.37 & 0.39 & 0.82 & 0.36 & 0.51 & 0.44 & 0.55 & 2.75 \\
$\mathrm{SiO}_{2}$ & 1.95 & 2.15 & 1.44 & 1.38 & 1.81 & 1.90 & 1.33 & 1.31 & 2.21 \\
$\mathrm{Al}_{2} \mathrm{O}_{3}$ & 0.36 & 0.23 & 0.33 & 0.32 & 0.28 & 0.27 & 0.32 & 0.38 & 0.39 \\
$\mathrm{MgO}$ & 1.44 & 1.47 & 0.92 & 0.31 & 0.31 & 0.43 & 0.35 & 0.76 & 1.45 \\
$\mathrm{CaO}$ & 0.34 & 0.40 & 1.09 & 1.29 & 0.36 & 0.25 & 1.33 & 1.22 & 0.39 \\
\hline
\end{tabular}


$\pm 5^{\circ} \mathrm{C}$ of the desired temperature.

\subsection{Degree of Reduction}

The degree of reduction was calculated according to the formula:

$$
R=\frac{\Delta W_{\mathrm{T}}-\Delta W_{\mathrm{M}}}{\Delta W_{\mathrm{O}}}
$$

$R:$ Degree of reduction

$\Delta W_{\mathrm{T}}:$ Total loss in weight

$\Delta W_{\mathrm{M}}$ : Loss in weight due to the removal of moisture

$\Delta W_{\mathrm{O}}$ : Total possible loss in weight due to oxygen removal

Total loss in weight was obtained by recording the change of weight of briquettes during reduction. Loss in weight due to the removal of moisture was obtained by recording the weight of similar briquettes heated in a nitrogen environment. Total possible loss in weight due to oxygen removal was obtained from TGA and cross-checked using the chemical analysis of individual components. An average value of three briquettes per test was accepted. A variation within $\pm 10 \%$ of the mean value was accepted.

\subsection{Chemical Analysis}

Chemical analysis was carried out using a Inductively Coupled Plasma (ICP) Spectrometer.

\subsection{Optical Microscopic Examination}

A test piece of the sample to be observed was cast in a cold-mounting epoxy resin mould under vacuum. The moulded sample was then ground and polished. The polished sample was then observed using a optical microscope.

\subsection{Particle Size Analysis}

Approximately $100 \mathrm{~g}$ of dried material was dry-sieved to various size fractions using a set of U.S. Standard Sieves conforming to ASTM. In this paper the particle size has been reported as $d_{50}$, which is the cumulative fifty percent finer than the value.

\subsection{Volume Measurements}

The bulk volume of briquettes and pellets was calculated under the assumption that they were perfectly cylindrical and spherical, respectively. The diameter and the length were measured using callipers. After reduction, the briquettes and pellets often distorted. Even in this case the diameter and length were measured at several places and an average of the readings was taken. This method of measuring the volume gave only rough values; hence, they should be taken only qualitatively.

\subsection{Effect of Particle Size $\left(d_{50}\right)$}

$900 \mathrm{~g}$ of Mix A or Mix B was ground in a steel ball mill for varying period of time $(1.0,2.5,5.0,7.5,10.0,15.0$, $120 \mathrm{~min}$ ). One set of material was also mixed for $30 \mathrm{~min}$ in a small porcelain jar by rotating the material (without balls). Thus, two sets of briquettes AA1-AA8 and $\mathrm{AB} 1-\mathrm{AB} 8$, comprising Mix A and Mix B, respectively, were prepared. Table 4 gives the average particle size $\left(d_{50}\right)$ of the raw materials used for making the briquettes.

\subsection{Effect of Pellet Type}

Eight different types of pellets $(\mathrm{A}-\mathrm{H})$ were crushed and made into cement-bonded briquettes, $\mathrm{BA}-\mathrm{BH}$, respectively. One set of briquettes (BPF) was also made using pelletfines. In each case, $1870 \mathrm{~g}$ of pellets were crushed and ground with $130 \mathrm{~g}$ of cement ( $6.5 \mathrm{wt} \%$ cement) for $3 \mathrm{~min}$ in
Table 4. Average particle size of raw materials of briquettes $\mathrm{AA} 1-\mathrm{AA} 8$ and $\mathrm{AB} 1-\mathrm{AB} 8$

\begin{tabular}{|l|c|c|c|c|c|c|c|c|}
\hline Sample & AA1 & AA2 & AA3 & AA4 & AA5 & AA6 & AA7 & AA8 \\
\hline Grinding & 120 & 15 & 10 & 7.5 & 5 & 2.5 & 1 & 0 \\
Time (min) & & & & & & & & \\
$\mathrm{d}_{50}(\mu \mathrm{m})$ & 30 & 70 & 149 & 253 & 1058 & 1595 & 2465 & 2512 \\
\hline
\end{tabular}

\begin{tabular}{|l|c|c|c|c|c|c|c|c|}
\hline Sample & $\mathrm{AB} 1$ & $\mathrm{AB} 2$ & $\mathrm{AB} 3$ & $\mathrm{AB} 4$ & $\mathrm{AB} 5$ & $\mathrm{AB} 6$ & $\mathrm{AB} 7$ & $\mathrm{AB} 8$ \\
\hline Grinding & - & - & 10 & 7.5 & 5 & 2.5 & 1 & 0 \\
Time (min) & & & & & & & & \\
$\mathrm{d}_{50}(\mu \mathrm{m})$ & - & - & 274 & 323 & 595 & 986 & 1337 & 2194 \\
\hline
\end{tabular}

a rod mill. The raw materials were then briquetted.

In the first set of experiments the briquettes were reduced for $5 \mathrm{~h}$ at $950^{\circ} \mathrm{C}$ in $\mathrm{N}_{2}$ : $\mathrm{CO}(60: 40)$. In the second set of experiments the briquettes were first reduced for $3 \mathrm{~h}$ in $\mathrm{N}_{2}: \mathrm{CO}: \mathrm{CO}_{2}(60: 4: 36)$, then for $3 \mathrm{~h}$ in $\mathrm{N}_{2}: \mathrm{CO}: \mathrm{CO}_{2}$ $(60: 20: 20)$ and finally for $4 \mathrm{~h}$ in $\mathrm{N}_{2}: \mathrm{CO}: \mathrm{CO}_{2}(60: 40: 0)$. In this way, the iron oxides in the briquettes first remained as magnetite for some time, then as wustite and finally as iron. This stepwise reduction allowed the system to homogenise to a greater degree. As a reference, uncrushed pellets were also reduced under similar conditions.

\subsection{Effect of Cement Content}

Two sets of briquettes containing $0,2,4,6,8,10,15,20$ and $25 \mathrm{wt} \%$ cement and the rest pellet-fines were prepared. The briquettes without any binder obviously did not have any strength but retained its shape during handling, due to the presence of moisture. One of the sets of briquettes, CF1-CF9, was prepared using finely ground pellet-fines and the other, $\mathrm{CC} 1-\mathrm{CC} 9$, using coarse pellet-fines.

In the first set of experiments the briquettes were reduced for $5 \mathrm{~h}$ at $950^{\circ} \mathrm{C}$ in $\mathrm{N}_{2}$ : $\mathrm{CO}(60: 40)$. In the second set of experiments the briquettes were first reduced for $3 \mathrm{~h}$ in $\mathrm{N}_{2}: \mathrm{CO}: \mathrm{CO}_{2}(60: 4: 36)$, then for $3 \mathrm{~h}$ in $\mathrm{N}_{2}: \mathrm{CO}: \mathrm{CO}_{2}$ $(60: 20: 20)$ and finally for $4 \mathrm{~h}$ in $\mathrm{N}_{2}: \mathrm{CO}: \mathrm{CO}_{2}(60: 40: 0)$.

\subsection{Effect of Hydration Time}

Two sets of briquettes (D1 and D2) were made according to the procedure given below. These briquettes were then reduced at $950^{\circ} \mathrm{C}$ in $\mathrm{N}_{2}+\mathrm{CO}(60: 40)$ for $5 \mathrm{~h}$.

D1: The green briquettes were made using coarse pelletfines $(93.5 \mathrm{wt} \%)$ and cement $(6.5 \mathrm{wt} \%)$ and cured for 30 days.

D2: The green briquettes were made and immediately tested for swelling on reduction. This way the cement did not get sufficient time to hydrate and release hydrated lime (portlandite).

\subsection{Effect of Cement Composition}

Eight types of briquettes (E1-E8) were made using pellet-fines and different types of binders. These binders were made by mixing laboratory grade chemicals in a porcelain ball mill. The oxides were taken in the proportions in which they are present in ordinary Portland cement. The green briquettes were then cured for 30 days and then reduced for $3 \mathrm{~h}$ at $950^{\circ} \mathrm{C}$ in $\mathrm{N}_{2}+\mathrm{CO}(60: 40)$. The composition of the binders is given in the Table 5.

\subsection{Effect of Cement Property}

Three types of artificial binders were used for making briquettes. F1 was pure laboratory-grade hydrated lime and the other two types were cements made by firing a mixture 
Table 5. Summary of tests carried out to study the influence of various oxides on the swelling of briquettes.

\begin{tabular}{|l|c|c|c|c|}
\hline Expt. No. & $\begin{array}{c}\mathrm{Ca}(\mathrm{OH})_{2} \\
(71.80 \mathrm{wt} \%)\end{array}$ & $\begin{array}{c}\mathrm{SiO}_{2} \\
(21.58 \mathrm{wt} \%)\end{array}$ & $\begin{array}{c}\mathrm{MgO} \\
(2.87 \mathrm{wt} \%)\end{array}$ & $\begin{array}{c}\mathrm{Al}_{2} \mathrm{O}_{3} \\
(3.74 \mathrm{wt} \%)\end{array}$ \\
\hline E1 & $\sqrt{ }$ & $\sqrt{ }$ & $\sqrt{ }$ & $\checkmark$ \\
E3 & $\sqrt{ }$ & $\sqrt{ }$ & & \\
E4 & $\sqrt{ }$ & & & \\
E5 & $\sqrt{ }$ & & $\sqrt{ }$ & \\
E6 & $\sqrt{ }$ & & $\checkmark$ & $\checkmark$ \\
E7 & $\sqrt{ }$ & & & \\
E8 & $\sqrt{ }$ & & \\
\hline
\end{tabular}

of pure laboratory-grade $\mathrm{CaO}, \mathrm{SiO}_{2}$ (quartz), $\mathrm{MgO}, \mathrm{Al}_{2} \mathrm{O}_{3}$ and $\mathrm{Fe}_{2} \mathrm{O}_{3}$ in the same proportion as in ordinary cement at $1300^{\circ} \mathrm{C}$ for $3 \mathrm{~h}$.

F1: $\quad \mathrm{Ca}(\mathrm{OH})_{2}$

F2: $\quad \mathrm{Ca}(\mathrm{OH})_{2}(76.88 \mathrm{wt} \%)+\mathrm{SiO}_{2}(23.12 \mathrm{wt} \%)$

F3: $\quad \mathrm{Ca}(\mathrm{OH})_{2}(70.26 \mathrm{wt} \%)+\mathrm{SiO}_{2}(21.13 \mathrm{wt} \%)$

$+\mathrm{MgO}(2.77 \mathrm{wt} \%)+\mathrm{Al}_{2} \mathrm{O}_{3}(3.62 \mathrm{wt} \%)$

$+\mathrm{Fe}_{2} \mathrm{O}_{3}(2.22 \mathrm{wt} \%)$

The cement so formed did not contain $\beta-\mathrm{C}_{2} \mathrm{~S}$; instead, it contained $\gamma-\mathrm{C}_{2} \mathrm{~S}$. This is because in the absence of impurities, $\beta-\mathrm{C}_{2} \mathrm{~S}$ is not a stable phase at room temperature. During cooling from $1300^{\circ} \mathrm{C}$ to room temperature, it transforms to $\gamma-\mathrm{C}_{2} \mathrm{~S}$. Even in F3, only $\gamma-\mathrm{C}_{2} \mathrm{~S}$ was observed. Some $\mathrm{C}_{3} \mathrm{~S}$ was formed and some lime remained unreacted. Such cements were used for making briquettes. The briquettes did not attain any strength, since $\gamma-\mathrm{C}_{2} \mathrm{~S}$ did not hydrate, so the briquettes were carefully placed inside the furnace and reduced in the previously described way.

\subsection{Effect of Binder Type}

Five sets of briquettes were prepared using five different types of binders. The briquettes were prepared in the normal way using $6.5 \mathrm{wt} \%$ binder. The binders were prepared by mixing cement with $25 \mathrm{wt} \%$ of different oxides, taken in powdered form of laboratory-grade reagents, in a small table porcelain ball mill for half an hour. The briquettes contained:

G1: Cement

G2: $\quad 75$ wt $\%$ cement +25 wt $\% \mathrm{CaO}$ (as $\mathrm{Ca}(\mathrm{OH})_{2}$ ) Calcium hydroxide was taken instead of calcium oxide to prevent generation of heat on hydration.

G3: $75 \mathrm{wt} \%$ cement $+25 \mathrm{wt} \% \mathrm{SiO}_{2}$ (as quartz)

G4: $\quad 75 \mathrm{wt} \%$ cement $+25 \mathrm{wt} \% \mathrm{MgO}$

G5: $75 \mathrm{wt} \%$ cement $+25 \mathrm{wt} \% \mathrm{Al}_{2} \mathrm{O}_{3}$

In the first set of experiments, the briquettes were reduced for $5 \mathrm{~h}$ at $950^{\circ} \mathrm{C}$ in $\mathrm{N}_{2}$ : $\mathrm{CO}(60: 40)$. In the second set of experiments, the briquettes were first reduced for $3 \mathrm{~h}$ in $\mathrm{N}_{2}: \mathrm{CO}: \mathrm{CO}_{2}(60: 4: 36)$, then for $3 \mathrm{~h}$ in $\mathrm{N}_{2}: \mathrm{CO}: \mathrm{CO}_{2}$ $(60: 20: 20)$ and finally for $4 \mathrm{~h}$ in $\mathrm{N}_{2}: \mathrm{CO}: \mathrm{CO}_{2}(60: 40: 0)$.

\subsection{Effect of Alkalis}

Two sets of samples (H1 and H2) were prepared using finely ground pellet-fines $(93.5 \mathrm{wt} \%)$ and cement $(6.5 \mathrm{wt} \%)$. In set $\mathrm{H} 21 \mathrm{wt} \%$ sodium silicate was also added and mixed. The two sets of briquettes were reduced at $950^{\circ} \mathrm{C}$ in $\mathrm{N}_{2}+\mathrm{CO}(60: 40)$ for $5 \mathrm{~h}$.
Table 6. Summary of tests carried out to study the influence of coke on the swelling of briquettes.

\begin{tabular}{|l|c|c|c|c|}
\hline & $\begin{array}{c}\text { Pellet-fines } \\
(\mathrm{w} \%)\end{array}$ & $\begin{array}{c}\text { Cement } \\
(\mathrm{w} \%)\end{array}$ & $\begin{array}{c}\text { Coke } \\
(\mathrm{w} 1 \%)\end{array}$ & $\begin{array}{c}\mathrm{d}_{50} \\
(\mu \mathrm{m})\end{array}$ \\
\hline IF1 & 93.5 & 6.5 & 0 & $<74$ \\
IF2 & 91.5 & 6.5 & 2 & $<74$ \\
IF4 & 89.5 & 6.5 & 4 & $<74$ \\
IF5 & 87.5 & 6.5 & 6 & $<74$ \\
\hline IC1 & 85.5 & 6.5 & 8 & $<74$ \\
IC2 & 93.5 & 6.5 & 0 & 2040 \\
IC3 & 91.5 & 6.5 & 2 & 2120 \\
\hline
\end{tabular}

\subsection{Effect of Coke Content}

Eight types of briquettes (IF1-IF5 and IC1-IC3) were made according to the normal procedure. These briquettes contained varying amounts of coke fines. Table 6 gives the composition and average particle size of the raw mix used. The cured briquettes were then reduced at $950^{\circ} \mathrm{C}$ either using only $\mathrm{N}_{2}$ for $3 \mathrm{~h}$ or using $\mathrm{N}_{2}+\mathrm{CO}(60: 40)$ for $3 \mathrm{~h}$.

\subsection{Effect of Briquette Size}

In order to study the effect of briquette size on swelling, one briquette was cut into smaller pieces of different sizes. All these samples were reduced at $950^{\circ} \mathrm{C}$ for $1.5 \mathrm{~h}$ in $\mathrm{N}_{2}: \mathrm{CO}(60: 40)$.

J1-J5: 5 pieces measuring $2 \mathrm{~cm} \times 1.5 \mathrm{~cm} \times(1.2-1.6) \mathrm{cm}$

J6: $1 \mathrm{~mm}$ thin section of briquette $(4.2 \mathrm{~cm}$ diameter $)$

J7: Some big particles of pellet-fines coated with cement

\subsection{Effect of Pre-firing}

Two sets of briquettes (K1 and K2) were prepared using coarsely ground pellet-fines and $6.5 \mathrm{wt} \%$ cement. Both these sets of briquettes were cured for $28 \mathrm{~d}$. After curing, the second set, K2, was heated in a muffle furnace at $1275^{\circ} \mathrm{C}$ for $0.5 \mathrm{~h}$. The cooled briquettes $\mathrm{K} 2$ had glassy coating over all the pellet-fines particles. The briquettes were then reduced at $950^{\circ} \mathrm{C}$ using $\mathrm{N}_{2}+\mathrm{CO}(60: 40)$ for $5 \mathrm{~h}$.

\section{Results and Discussion}

\subsection{Effect of Particle Size $\left(d_{50}\right)$}

Figure 1 shows the effect of particle size $\left(d_{50}\right)$ on the swelling of briquettes. Briquette AA1 does not show any catastrophic degradation. As the particle size $\left(d_{50}\right)$ increases, the swelling also increases. This is due to the formation of large cracks as well as popping-up of large particles. Overall, the volume change is almost proportional to the $\log$ of $d_{50}$ of the raw mix.

Figure 2 shows the optical micrographs of the reduced samples. From the figure, it is seen that in the briquette AA1, the fine pellet-fines particles are surrounded by matrix. On heating, the matrix breaks and becomes porous. When the small pellet-fines particles reduce, disintegrate and scatter they occupy the space originally occupied by the matrix. There is some dispersion of grains on the transformation of wustite to iron but not much, hence, there is not much swelling. In the case of briquette AA8, as the reduction of hematite $\rightarrow$ magnetite $\rightarrow$ wustite $\rightarrow$ iron proceeds, the 

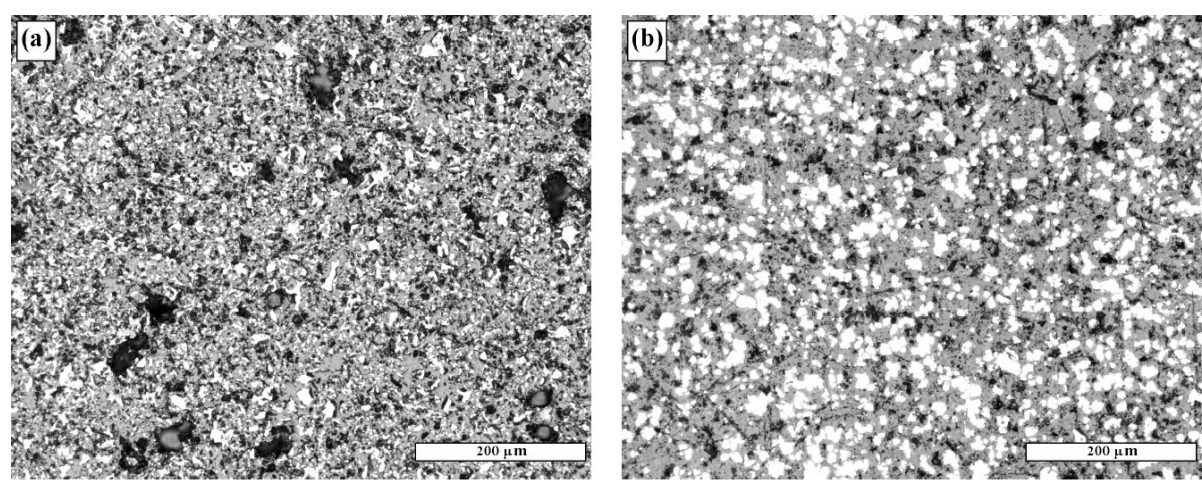

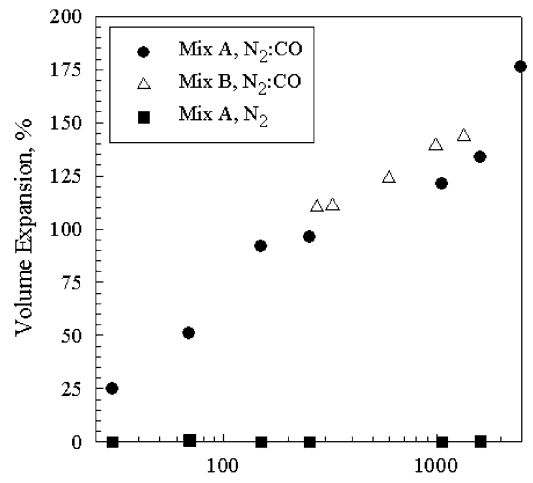

$\mathrm{d}_{50}, \mu \mathrm{m}$

Fig. 1. Effect of average particle size on the volume of briquettes. (Reduction temperature $=950^{\circ} \mathrm{C}$, time $=3 \mathrm{~h}, \mathrm{~N}_{2}: \mathrm{CO}=60: 40$ )
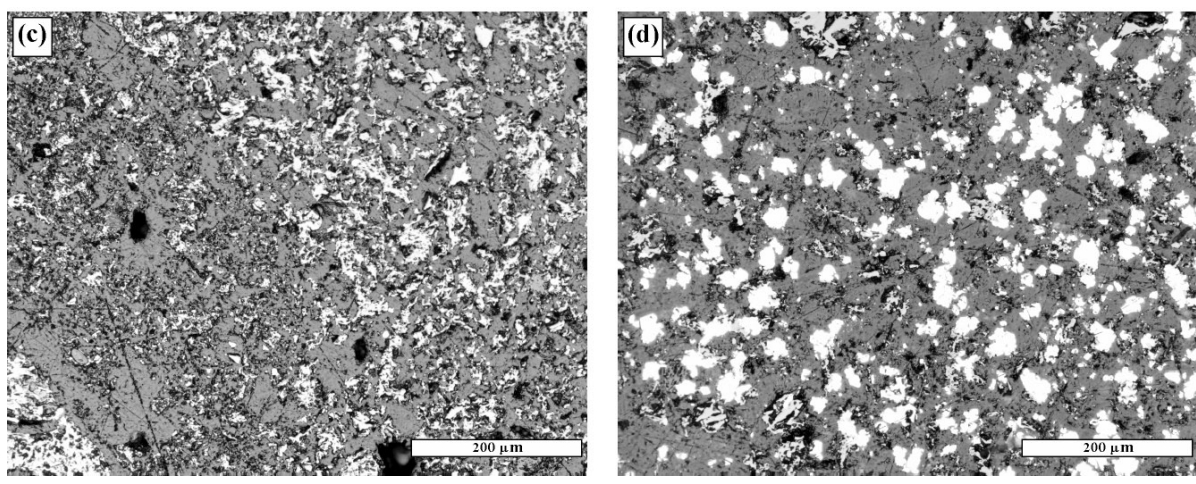

Fig. 2. Optical micrographs of briquettes AA1 $\left(d_{50}<74 \mu \mathrm{m}\right)$ and AA8 $\left(d_{50}=2465 \mu \mathrm{m}\right)$ after reduction in $\mathrm{N}_{2}$ : CO for $3 \mathrm{~h}$ at $950^{\circ} \mathrm{C}$. (a) AA1 $\left(d_{50}<74 \mu \mathrm{m}\right)$ centre (light grey particles are wustite, dark grey particles are dehydrated cement); (b) AA1 $\left(d_{50}<74 \mu \mathrm{m}\right)$ periphery (white particles are iron, dark grey particles are dehydrated cement); (c) AA8 $\left(d_{50}=2465 \mu \mathrm{m}\right)$ centre (light grey particles are wustite, dark grey particles are dehydrated cement); and (d) AA8 $\left(d_{50}=\right.$ $2465 \mu \mathrm{m}$ ) periphery (white particles are iron, dark grey particles are dehydrated cement). dispersion of grains increases and the size of grains decreases. During wustite $\rightarrow$ iron reduction, the scattering reaches a maximum. This disintegration and "explosion" of the original large particles leads to the popping-up of large grains. When there are many large grains in one area and there is not enough space to scatter, they push against each other, resulting in an overall swelling of the briquettes. This is evidenced by the fact that at the left side of the micrograph the complete particle is more densely packed than the right. This means that while the pellet particle was free to swell to its maximum on the open side, the swelling was more restricted on the closed side.

When the Pellet $A$ is reduced in an $\mathrm{N}_{2}$ : $\mathrm{CO}(60: 40)$ environment at $950^{\circ} \mathrm{C}$ the reduction of hematite $\rightarrow$ magnetite $\rightarrow$ wustite $\rightarrow$ iron proceeds without catastrophic swelling of the pellets. Under such conditions, the hematite/ magnetite/wustite grains are of laminar shape and rather large. In the case of pellets, the reduction of wustite to iron is completely caused by solid-gas reaction. The reduced iron remains bound to the wustite and cannot move freely; hence, it forms relatively large, laminar and interconnected iron grains.

\subsection{Effect of Pellet Type}

Figure 3 shows that, except for Pellet B, none of the pellets have any tendency to swell catastrophically. Even Pellet B does not show swelling due to formation of spongy mass, as is the case for the briquettes, or formation of iron whiskers; instead, the large-scale swelling is due to formation of a "mouth", i.e., a big crack running along its equator. This clearly shows that pellets themselves do not have any swelling tendencies. When the pellets are crushed and made into cement-bonded briquettes, some briquettes, no- tably BB, BC, BD, BG and BH, develop a tendency to swell catastrophically. It also shows that, in almost all cases, the briquettes reduced in one step swell more than the briquettes reduced in three steps.

Figures 4 and 5 show the effect of temperature on the swelling of briquettes made of different types of crushed pellets. All the types of briquettes swell the most at $950^{\circ} \mathrm{C}$. The figures show that briquettes BA, BE \& BF swell relatively less than the briquettes made of other types of pellets.

Figure 6 shows the optical micrographs of reduced cement-bonded briquettes BA and BB. It can be seen that in the centre of briquette BA the individual grains of wustite are more densely packed than the grains of wustite in the centre of briquette BB. The micrographs also show that at the peripheral position of briquette BA, the iron particles are larger and more compact than those at the corresponding position of the briquette BB. Microscopic observations of reduced briquettes made using other types of crushed pellets show that the briquettes that have a tendency to swell $(\mathrm{BB}, \mathrm{BC}, \mathrm{BG}$ and $\mathrm{BH})$ disintegrate at the wustite stage and scatter on reduction to iron.

Figures 7 and $\mathbf{8}$ show the relationship between the volume expansion and the presence of slag-forming oxides, $\mathrm{CaO}, \mathrm{SiO}_{2}, \mathrm{MgO}$ and $\mathrm{Al}_{2} \mathrm{O}_{3}$ in the pellets. The figures show that the swelling may increase with increasing slag-forming oxide content. The figure also shows that for the swelling to take place the ratio of basic oxides to acidic oxides $\left(\mathrm{CaO}+\mathrm{MgO} / \mathrm{SiO}_{2}+\mathrm{Al}_{2} \mathrm{O}_{3}\right)$ should be about one. The figures also show that the briquettes made of pellet-fines swell much more than the briquettes made of crushed Pellet A, even though the pellet-fines consists of fines of approximately $75 \mathrm{wt} \%$ Pellet A and $25 \mathrm{wt} \%$ Pellet B. One of the reasons may be the presence of Pellet $\mathrm{B}$, which swells much 


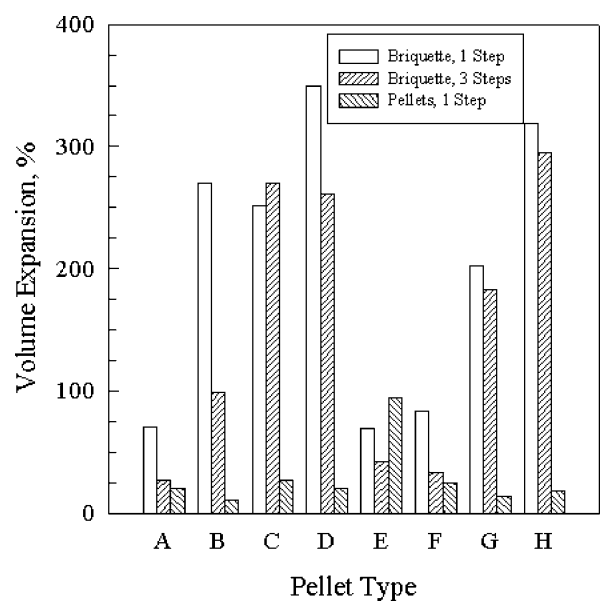

Fig. 3. Effect of pellet-type on the swelling of briquette and pellets after reduction in one step and of briquette after reduction in three steps at $950^{\circ} \mathrm{C}$.

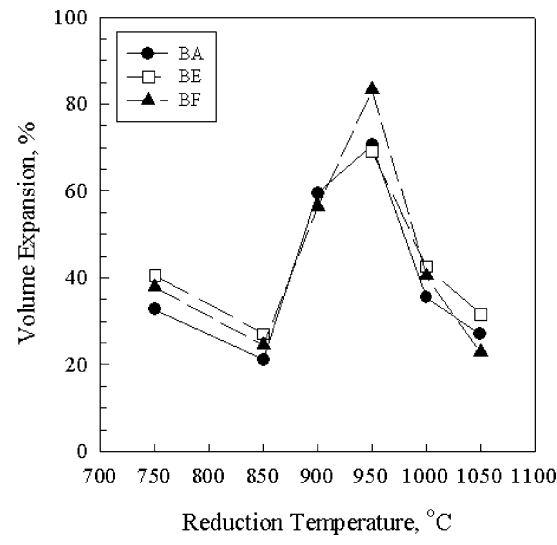

Fig. 4. Effect of temperature on the swelling of briquettes made of different types of pellets reduced for $5 \mathrm{~h}$ in $\mathrm{N}_{2}+\mathrm{CO}(60: 40)$.

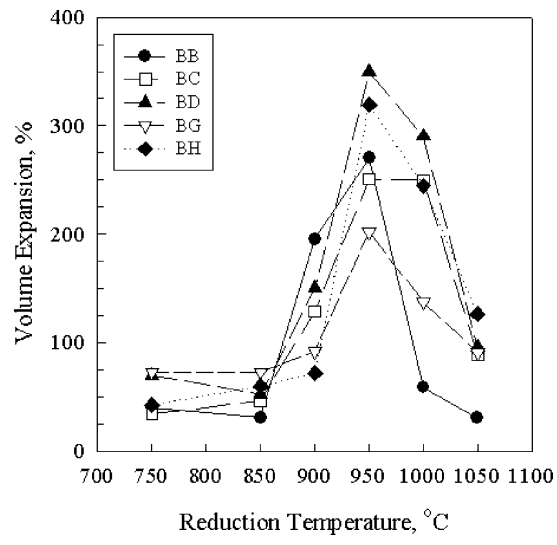

Fig. 5. Effect of temperature on the swelling of briquettes made of different types of pellets reduced for $5 \mathrm{~h}$ in $\mathrm{N}_{2}+\mathrm{CO}(60: 40)$.

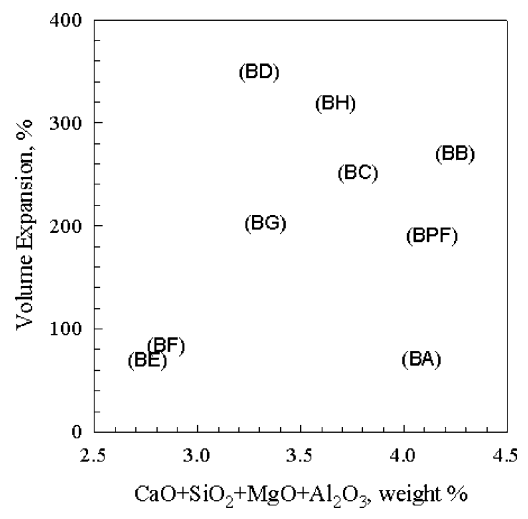

Fig. 7. Effect of amount of slag forming oxides on the swelling of briquettes made of various pellet types reduced for $5 \mathrm{~h}$ at $950^{\circ} \mathrm{C}$ in $\mathrm{N}_{2}+\mathrm{CO}(60: 40)$.

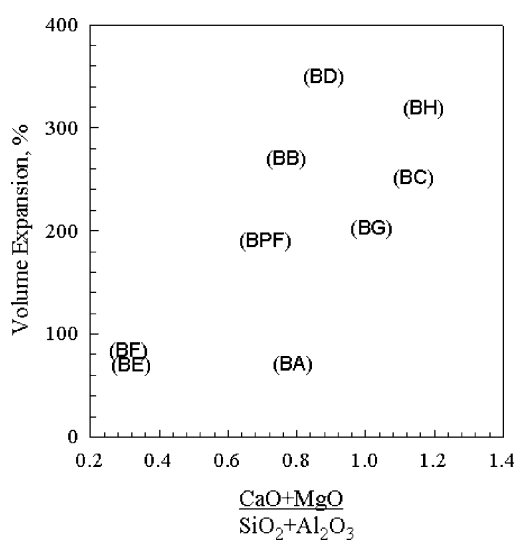

Fig. 8. Effect of basicity on the swelling of briquettes made of various pellet types reduced for $5 \mathrm{~h}$ at $950^{\circ} \mathrm{C}$ in $\mathrm{N}_{2}+\mathrm{CO}(60: 40)$

\subsection{Effect of Cement Content}

Figure 10 shows the effect of cement as binder on the swelling of briquettes reduced in one step. Figure 11 shows that the briquettes reduced in one step exhibits maximum swelling at $4 \%$ cement, thereafter, the swelling decreases. Interestingly, the briquette without any binder $(0 \%$ cement $)$ 

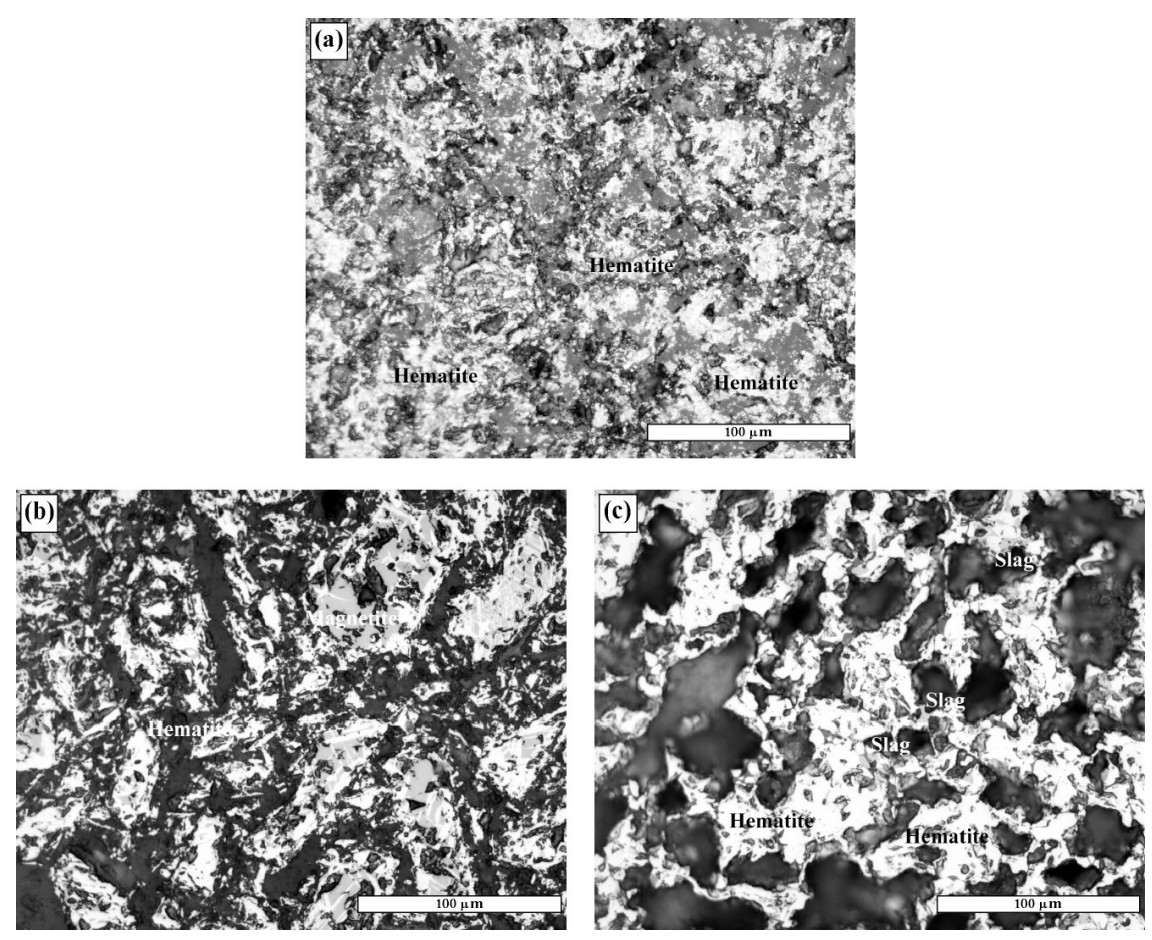

Fig. 9. Optical micrographs of Pellet A and pellet-fines particles, (a) Pellet A (grey areas are hematite), (b) Pelletfines particles (light grey regions are hematite and the dark grey are magnetite), and (c) Pellet-fines particles (light grey regions are hematite and the dark grey are slag).

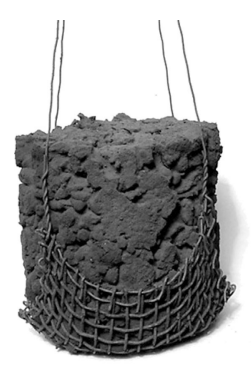

$0 \%$

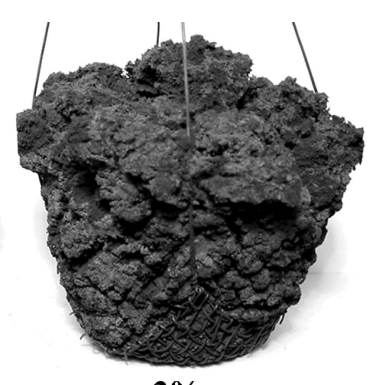

$2 \%$

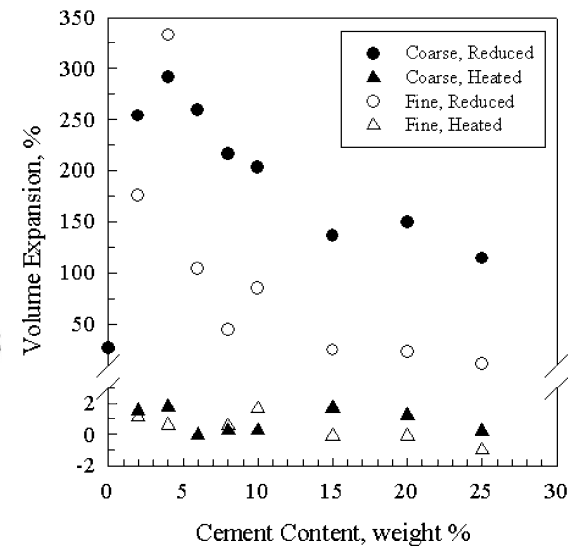

Fig. 11. Effect of cement content on the swelling of briquettes heated in nitrogen environment at $950^{\circ} \mathrm{C}$ for $5 \mathrm{~h}$ and reduced in $\mathrm{N}_{2}: \mathrm{CO}$ $(60: 40)$ at $950^{\circ} \mathrm{C}$ for $5 \mathrm{~h}$.

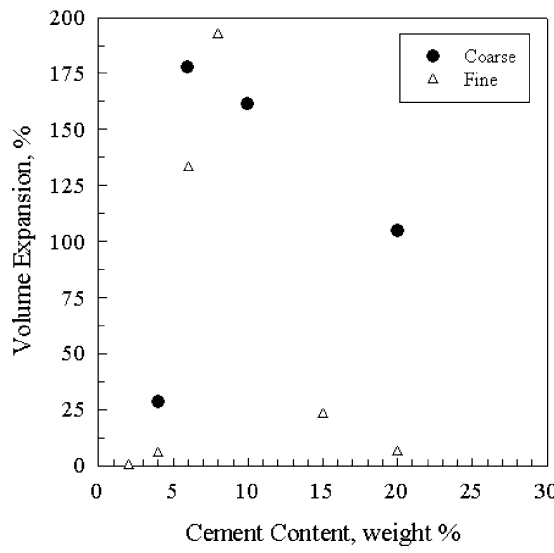

Fig. 12. Effect of cement content on the swelling of briquettes reduced in steps. (Reduction time $3 \mathrm{~h}$ for $\mathrm{CO} / \mathrm{CO}+\mathrm{CO}_{2}=0.1,3 \mathrm{~h}$ for $\mathrm{CO} /$ $\mathrm{CO}+\mathrm{CO}_{2}=0.5,4 \mathrm{~h}$ for $\mathrm{CO} / \mathrm{CO}+$ $\left.\mathrm{CO}_{2}=1\right)$. does not swell catastrophically. This clearly shows that for catastrophic swelling to take place the presence of cement is essential.

The decrease in swelling with increase in cement content for the briquettes made of coarse raw mix, $\mathrm{CC} 1-\mathrm{CC} 9$, may be due to the following: (a) decrease in $d_{50}$ of raw mixture due to increase in finely ground cement content; (b) decrease in the amount of pellet-fines; and (c) changes in the reaction mechanism.

Previous studies have shown a rather modest swelling when the briquettes made of finely ground material containing $6.5 \mathrm{wt} \%$ cement are reduced. Figure 11 shows that even the briquettes made of finely ground raw material containing $4 \mathrm{wt} \%$ cement can show catastrophic swelling. Hence, in order to control abnormal swelling, not only should the raw material be ground finely, but the amount of cement should also be controlled.

Figure 12 shows the effect of cement on the swelling of briquettes that have been reduced in steps. The figure shows a shift in the maximum point. Here, the maximum swelling takes place for the briquettes made using $6-8 \mathrm{wt} \%$ cement.

Figure 13 shows the optical micrographs of briquettes, $\mathrm{CC} 1, \mathrm{CC} 2$ and $\mathrm{CC} 9$, made of coarse material. In the case of the briquette containing no cement, the reduced iron particles are laminar in structure and compactly bound. In the case of the briquette containing $2 \mathrm{wt} \%$ cement, on reduction, a pellet-fines particle initially severs to pieces and then spreads out. On the other hand, even though the pellet-fine particles in the briquette containing $25 \mathrm{wt} \%$ cement break to pieces, the pieces are not so free to disseminate. This, along with presence of non-swelling dicalcium silicate particles (from dehydration of cement gel), prevents abnormal swelling of the briquettes. Hence, the strength is higher in the case of briquettes having more cement.

\subsection{Effect of Hydration Time}

On reduction, it is observed that the briquettes swell catastrophically in both cases (D1 and D2), indicating that the 

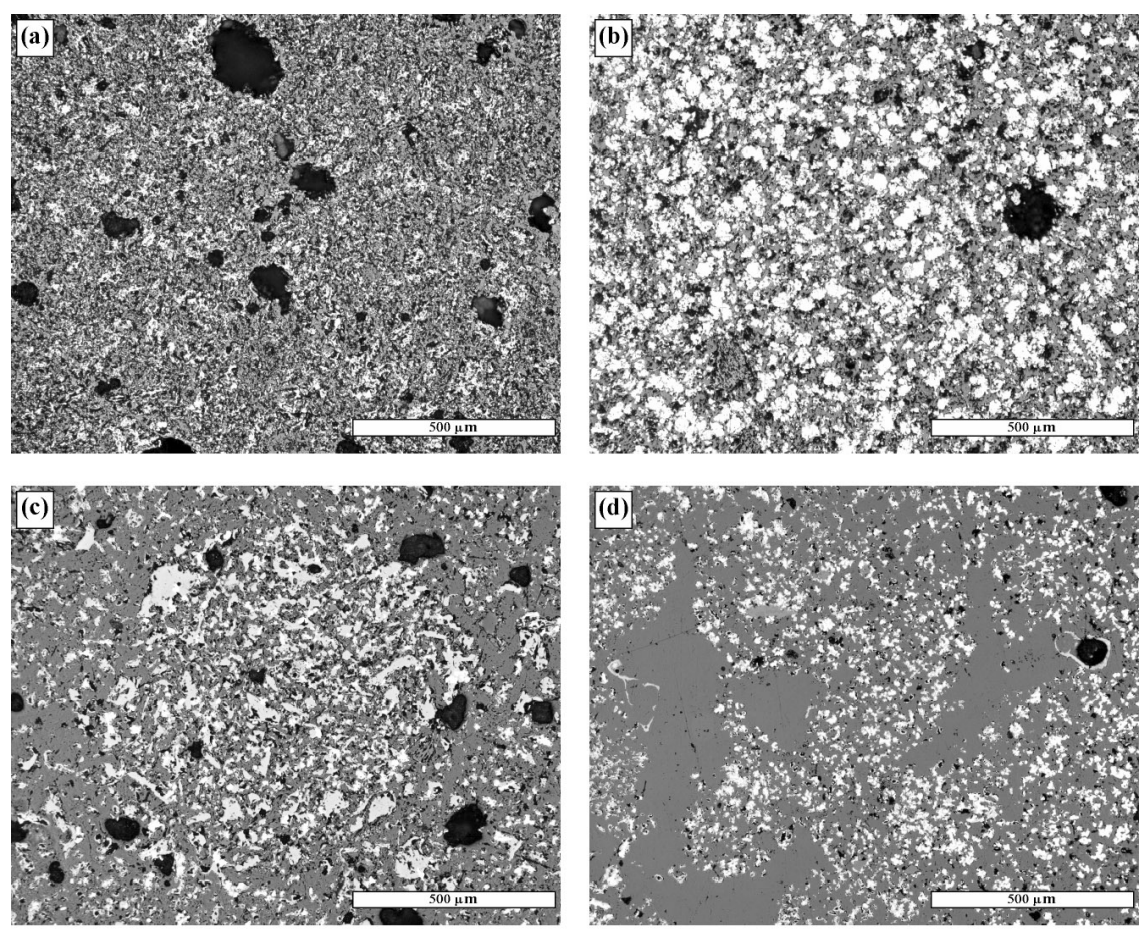

Fig. 13. Optical micrographs of briquettes CC1 (pellet-fines $+0 \%$ cement), $\mathrm{CC} 2$ (pellet-fines $+2 \%$ cement); and CC9 (pellet-fines $+25 \%$ cement) reduced in $\mathrm{N}_{2}: \mathrm{CO}$ for $5 \mathrm{~h}$ at $950^{\circ} \mathrm{C}$. (a) $\mathrm{CC} 1(0 \%$ cement $)$ centre (grey particles are wustite); (b) $\mathrm{CC} 1$ ( $0 \%$ cement) periphery (white particles are iron); (c) $\mathrm{CC} 2$ ( $2 \%$ cement) centre (grey particles are wustite); (d) CC2 (2\% cement) periphery (white particles are iron). (e) CC9 (25\% cement) centre (grey particles are wustite, dark grey particles are dehydrated cement); and (f) CC9 (25\% cement) periphery (white particles are iron, dark grey particles are dehydrated cement).

hydration of cement and release of free lime are not necessary conditions for swelling to take place.

The most important phases in ordinary Portland cement are the calcium silicates $\left(\mathrm{C}_{3} \mathrm{~S}\right.$ and $\left.\beta-\mathrm{C}_{2} \mathrm{~S}\right)$. These calcium silicates react with water to form calcium silicate hydrates of variable composition and structure (classified under a general term $\mathrm{C}-\mathrm{S}-\mathrm{H}$ gel). The structure of $\mathrm{C}-\mathrm{S}-\mathrm{H}$ gel depends on, among other factors, $\mathrm{C} / \mathrm{S}, \mathrm{S} / \mathrm{H}$, time of hydration, $\mathrm{pH}$ of slurry and presence of other compounds/impurities. The composition of the gel can be expressed by a very rough approximation as $\mathrm{C}_{3} \mathrm{~S}_{2} \mathrm{H}_{3}\left(\mathrm{Ca}_{3} \mathrm{Si}_{2} \mathrm{O}_{7} \cdot 3 \mathrm{H}_{2} \mathrm{O}\right)$ and the reactions involved as:

$$
\begin{aligned}
& \mathrm{C}_{3} \mathrm{~S}+x \mathrm{H} \rightarrow \mathrm{C}_{y} \mathrm{SH}_{(x+y-3)}+(3-y) \mathrm{CH} \\
& \mathrm{C}_{2} \mathrm{~S}+x \mathrm{H} \rightarrow \mathrm{C}_{y} \mathrm{SH}_{(x+y-2)}+(2-y) \mathrm{CH}
\end{aligned}
$$

In this experiment, the role of silicate, calcium silicate hydrate and hydrated lime in the swelling two sets of briquettes has been investigated. The results of the experiment show that the presence of free lime is not necessary for swelling to take place; instead, it is the presence of all the slag-forming oxides together in the briquettes that is the cause of swelling.

\subsection{Effect of Cement Composition}

When the briquettes are reduced isothermally at $950^{\circ} \mathrm{C}$, it is observed that the maximum swelling takes place in the presence of all the four oxides (briquette E1). To a lesser degree, the swelling takes place in the presence of $\mathrm{CaO}$, $\mathrm{SiO}_{2}$ and $\mathrm{MgO} / \mathrm{Al}_{2} \mathrm{O}_{3}$ (briquettes $\mathrm{E} 2$ and $\mathrm{E} 3$ ). In the ab- sence of $\mathrm{SiO}_{2}, \mathrm{MgO}$ or $\mathrm{Al}_{2} \mathrm{O}_{3}$ (briquettes E4-E8), swelling does not take place. In any case, the swelling is considerably less than the swelling that takes place in the cementbonded briquettes. This is probably due to the inhomogeneous nature of mixture of these oxides. This experiment also shows that free lime, alkalis and sulphur present in commercial cement are not the cause of swelling.

\subsection{Effect of Cement Property}

It is observed that briquettes F1 and F2 do not swell appreciably. The only swelling is due to cracking. On the other hand, the F3 briquettes swell catastrophically. This experiment clearly shows that the presence of free lime, or only lime and silica, is not a sufficient condition for swelling to take place.

\subsection{Effect of Binder Type}

Figure 14 shows the effect of various binders on the swelling of briquettes (G1-G5) when reduced for $5 \mathrm{~h}$ in $\mathrm{N}_{2}+\mathrm{CO}(60: 40)$ and when reduced in three steps using $\mathrm{N}_{2}: \mathrm{CO}: \mathrm{CO}_{2}=60: 35: 5$ for $3 \mathrm{~h}, 60: 20: 20$ for $3 \mathrm{~h}$ and $60: 40: 0$ for $4 \mathrm{~h}$ at $950^{\circ} \mathrm{C}$. The figure shows that when a part of cement is replaced by the oxide the briquettes tend to swell less. This suggests the possibility of lowering the swelling tendency by incorporating hydrated lime, silica fumes or crushed magnesia/alumina bricks in the cement. It may also be possible to lower the swelling by using highstrength cement, which has relatively higher $\mathrm{CaO} / \mathrm{SiO}_{2}$ ratio as compared to ordinary Portland cement. 


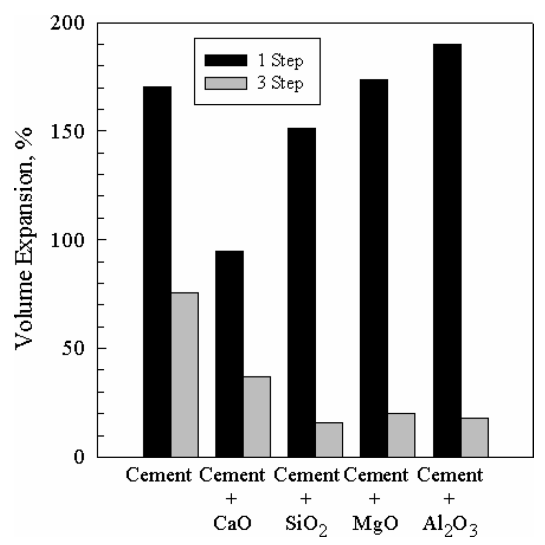

Fig. 14. Effect of various binders on the swelling of briquettes (G1-G5) reduced at $950^{\circ} \mathrm{C}$ for $5 \mathrm{~h}$ in $\mathrm{N}_{2}+\mathrm{CO}(60: 40)$ environment and reduced at $950^{\circ} \mathrm{C}$ in three steps using $\mathrm{N}_{2}: \mathrm{CO}: \mathrm{CO}_{2}=$ $60: 35: 5$ for $3 \mathrm{~h}, 60: 20: 20$ for $3 \mathrm{~h}$ and $60: 40: 0$ for $4 \mathrm{~h}$.

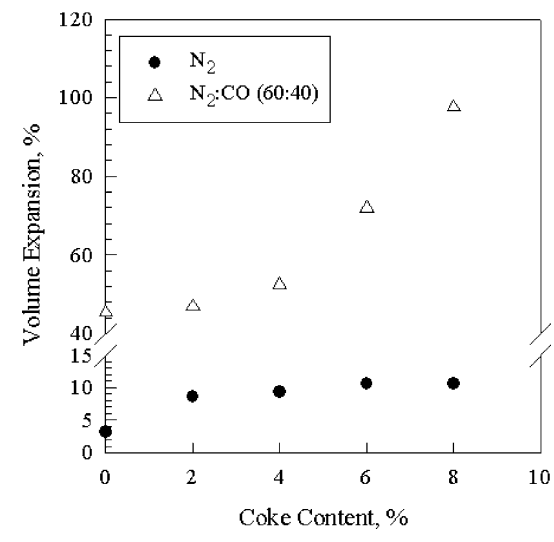

Fig. 15. Effect of coke content on the swelling of briquettes made of finely ground raw material (IF1-IF5).

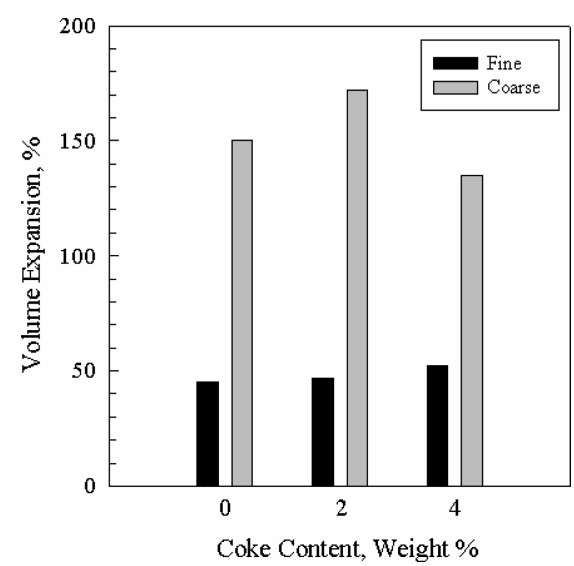

Fig. 16. Effect of coke content on the swelling of briquettes (IF1-IF3 and $\mathrm{IC} 1-\mathrm{IC} 3$ ).
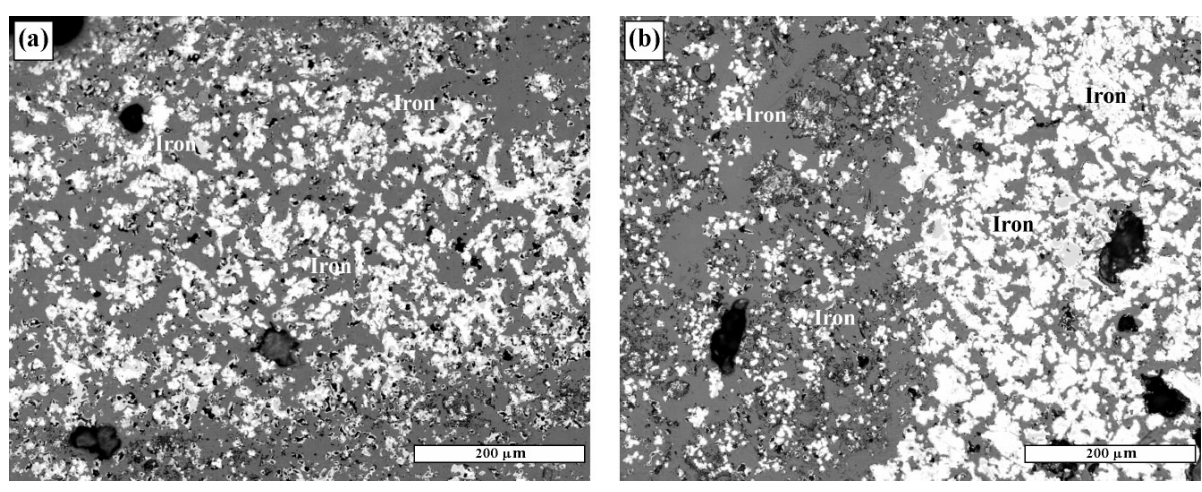

Fig. 17. Optical micrographs of a thin section (J6) reduced at $950^{\circ} \mathrm{C}$ in $\mathrm{N}_{2}: \mathrm{CO}=60: 40$, (a) scattered iron particles, which was originally a small pellet-fines particle, and (b) region adjoining a large particle. (white particles are iron).

\subsection{Effect of Alkalis}

On reduction, it has been observed that $\mathrm{H} 1$ does not swell; on the other hand, H2 shows catastrophic swelling. The earlier experiments have shown that the presence alkali is not essential for swelling to take place. This experiment shows that in the presence of alkali the swelling drastically increases. The presence of alkali can even cause the briquettes made of finely ground raw material to swell.

\subsection{Effect of Coke Content}

Figure 15 shows the effect of coke content on the swelling of briquettes made using finely ground raw material (briquettes IF1-IF5). The figure shows that in case of heating in nitrogen swelling does not take place. On the other hand, when the briquettes are reduced in $\mathrm{N}_{2}+\mathrm{CO}$ $(60: 40)$ the swelling increases with increase in coke content. The main reason may be the low degree of reduction that takes place in the case of briquettes heated in $\mathrm{N}_{2}$. This experiment shows that sudden gasification of coke does not cause rupture and disintegration.

Figure 16 shows the effect of coke content on the briquettes made of finely and coarsely ground raw materials (IF1-IF3 and IC1-IC3). The figure shows that swelling takes place more in the case of IC1-IC3 than in the case of IF $1-I F 3$. It also shows that up to $4 \mathrm{wt} \%$ coke content, coke content has no effect on the swelling of briquettes.

\subsection{Effect of Briquette Size}

All the briquette pieces (J1-J6) show abnormal swelling of $200-400 \%$. Even the big cement-coated pellet-fines par- ticles (J7) swell. The optical micrograph of a reduced piece shows a structure that is similar to that of the reduced complete briquette. This shows that the swelling behaviour is independent of the size of sample.

Close examination of reduced sample J6 shows swelling tendencies along the rim of the pellet-fines particles. The inner portions of the large particles do not show such swelling. Figure 17 shows the optical micrographs of the thin section from region (a), a small particle between two large particles, and (b), adjoining a large pellet-fines particle. The micrographs clearly show that small particles influenced by cement from all sides show considerable swelling. On the other hand, in the case of the large particle, the outer portions, where cement may have been present, show swelling, but the region away from the surface, which may not have been influenced by cement, does not show swelling.

\subsection{Effect of Pre-firing}

The briquettes K1 show catastrophic swelling; on the other hand, the briquettes K2 do not show swelling. Figure 18 shows the optical micrographs of the fired and reduced briquettes. It can be seen that due to the reaction between cement and hematite, additional slag is generated (Fig. 18(a)). This slag diffuses into the pellet-fines particles and forms additional bonding. This slag bonding prevents the disintegration of pellet-fines on reduction to wustite (Fig. $18(\mathrm{~b}))$. On further reduction, first the wustite is reduced and then the iron oxide component of the slag. As a result, the slag bonding is not destroyed till the late stage. The iron 

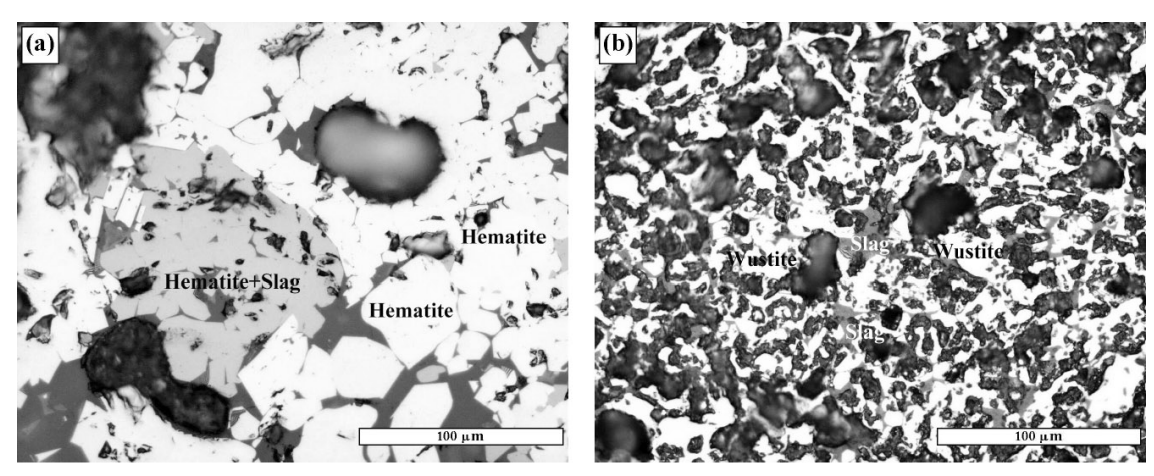

Fig. 18. Optical micrographs of briquettes K2 showing the effect of pre-firing, (a) heating at $1275^{\circ} \mathrm{C}$ for $0.5 \mathrm{~h}$ (light grey grains are hematite and dark grey grains are slag coated hematite particles); (b) centre of reduced briquette (light grey grains are wustite and the dark grey grains are slag bonding); (c) transition boundary of reduced briquette (white grains are iron and grey grains are wustite); and (d) periphery of reduced briquette (white region is iron and grey region is wustite).

grains produced after reduction are large, laminar and interconnected (Fig. 18(d)). Hence, there is no swelling of the briquette.

The other reason for the low degree of swelling of briquettes K2 may be the stronger structure of pellet-fines particles. In a comparison of the structure of pellet-fines in Fig. 6 , it can be seen that the grains of hematite (Fig. 18(a)) become more sintered and crystalline upon heating. This improves the strength of the pellet-fines particles. On reduction, the stronger structure of pellet-fines would prevent the grains from disintegrating.

\section{Conclusions}

From the work carried out it may be concluded that:

(1) The swelling of briquettes increases with the increase in average particle size of the raw material. The swelling is almost proportional to the $\log$ of $d_{50}$ of the raw mix.

(2) The swelling depends upon the type of pellets used for making briquettes. Briquettes made using pellets containing a larger amount of slag-forming oxides, $\mathrm{CaO}, \mathrm{SiO}_{2}$, $\mathrm{MgO}$ and $\mathrm{Al}_{2} \mathrm{O}_{3}$ may swell more.

(3) The briquettes made of pellet-fines particles swell much more than those made of crushed Pellet A, even though the $75 \mathrm{wt} \%$ of pellet-fines particles are broken Pellet A. This is because it is mostly the under-fired and weaker Pellet A that breaks and ends up as pellet-fines particles.

(4) The swelling is not significant in the absence of cement. It reaches a maximum when the briquette contains about $4-6 \mathrm{wt} \%$ cement.

(5) Swelling is not caused by the presence only of free lime in the hydrated cement; it is caused by the presence of all slag-forming oxides.

(6) Replacing a part of the cement with lime, silica, magnesia or alumina may decrease the swelling.

(7) Swelling is not caused by the presence of alkalis in the cement, but the swelling behaviour of the briquettes can be enhanced by the addition of alkalis.

(8) The presence of up to $4 \mathrm{wt} \%$ coke in the briquette does not affect the swelling of briquettes, but beyond this value it increases the swelling.

(9) The size of the briquette has no influence on swelling characteristics.

(10) The swelling of briquettes can be prevented if the briquettes are heated at high temperature (about $1275^{\circ} \mathrm{C}$ ) in non-reducing atmosphere prior to reduction. The heating causes cement to react with hematite and form slag. On cooling, the slag forms bonding matrix. Due to high-temperature heating, the structure of pellet-fines particles are also strengthened.

\section{Acknowledgements}

This work was carried out within MiMeR (Minerals and Metals Recycling Research Centre) at Luleå University of Technology, Sweden. It was partly financed by VINNOVA (the Swedish Agency for Innovation Systems) and a number of Swedish metallurgical industries. The authors are grateful for the suggestions and overall support of their colleagues at MiMeR.

\section{REFERENCES}

1) G. Berglund and L. E. Eriksson: Proc. of Pretreatment and Reclamation of Dusts, Sludges and Scales in Steel Plants, Hamilton, Canada, McMaster Symposium No. 21, ed. by W. K. Lu, ISS Publication, Warrendale, PA, USA (1993), 94.

2) T. de Bruin and L. Sundqvist: ICSTI/Ironmaking Conf. Proc., ISS Publication, Warrendale, PA, USA (1998), 1263.

3) E. A. Bogdan, R. T. Wargo, K. L. Myklebust and D. G. White: Ironmaking Conf. Proc., 50 ISS Publication Warrendale, USA (1991), 69.

4) J. K. Wright: Trans. Iron Steel Inst. Jpn., 17 (1977), 726.

5) L. Gränse: Proc. ICSTIS, Section 1, Trans. Iron Steel Inst. Jpn. Suppl., 11 (1971), 45.

6) M. Jallouli, M. Rigaud and F. Ajersch: Proc. Agglomeration, 81 (1981), B81.

7) G. Thaning: Ironmaking Steelmaking, 2 (1976), 57.

8) Q. Zhou and C. Guo: Proc. Agglomeration, 85 (1985), 267.

9) W-K. Lu: Ironmaking Proc. Metall. Soc. AIME, 3 (1974), 61.

10) T. Sharma, R. C. Gupta and B. Prakash: ISIJ Int., 33 (1993), No. 4, 446.

11) J. T. Moon and R. D. Walker: Ironmaking Steelmaking (Quarterly), 1 (1975), 30 . 